YAK 331

ББК 65.24

DOI 10.22394/1682-2358-2020-5-85-92

V.A. Starostin, lecturer at Tauride Academy of V.I. Vernadsky Crimean Federal University

\section{DIGITALIZATION \\ OF LABOR RELATIONS \\ AND EMPLOYMENT \\ IN TECHNOGENIC SOCIETY}

Labor policy reforms are studied in connection with the expansion of digital technologies and changes in all spheres of public life. The features and risks of transition to the global digital sphere of IT technologies, the state of unemployment in conditions of economy digitalization, the characteristic of digital employment as a factor in solving the unemployment problem are determined.

Key words and word-combinations: working hours, social policy, labor relations, digitalization.
B.A. Старостин, преподаватель Таврической академии Кримского федерального университета им. В.И. Вернадского (email: vitaly199@mail.ru)

\section{АИГИТААИЗАЦИЯ ТРУАОВЫХ ОТНОШЕНИЙ И ЗАНЯТОСТИ B ТЕХНОГЕННОМ СОЦИУМЕ}

Аннотация. Исследуется реформирование политики трудовых отношений в связи с расширением цифровых технологий и изменением всех сфер общественной жизни. Определяются особенности и риски перехода к глобальной цифровой сфере IT-технологий, состояние безработицы в условиях дигитализации экономики, характеристике цифровой занятости как фактора решения проблемы безработицы.

Ключевые слова и словосочетания: рабочее время, социальная политика, трудовые отношения, дигитализация.

B настоящее время осуществляется переход мирового сообщества из постинАустриацьного к цифровому этапу развития. Прощесс развития IT-сферы влияет на все аспекты жкизни человека и общества. Это гмобамьный феномен, который требует существенного реформирования национацьных политических, межаународных, экономических, правовых и Аругих стратегий развития. Его относительная малоизученность позвоцяет преАположить возможные социаль- 
но-политические риски, связанные с постепенным вытеснением работников из сферы трудовой деятельности после замены их искусственным интелмектом. Аیя Российской Федерации процесс цифровизации и роботизации, расширения инноваџионных компьютерных технологий в сочетании с уровнем экономического развития особенно непреАсказуем и рискован. При игнорировании властями проџесса цифровизации трудовых отношений комплекс вызовов и угроз может способствовать соџиальной нестабильности в обществе, конфликтам интересов работников и работодателей, нарушению баланса общественно-политических институтов.

Безусловно, развитие информационных компьютерных технологий оказывает влияние на рынок труда и занятость населения. Формирование цифровой реальности и информационного пространства оказывает воздействие на появление нового содержания трудовых отношений. Например, появляются удаленные рабочие места с использованием Интернета.

Сфера развития IT-технологий способствует развитию нового цифрового этапа на рынке труда. Его основные аспекты: цифровизация труАовых отношений, расширение цифровой инфраструктуры, изменение сложившихся отношений межАу работником и работодателем. В настоящее время правовая регламентаџия цифровых трудовых отношений не установлена законодательством. В связи с этим формируется новый кмасс работников «прекариат», основной признак которого - неофиџиальное трудоустройство.

Формирование IT-технологий в трудовой сфере увеличивает спрос на занятость работников, что приводит к теневому росту безработиџы изза институџиональной структуры или негибкости рынка труда. Такие отношения часто офиџиально не оформляются. В связи с этим возможно сокращение безработиџы на рынке труда за счет применения цифровых форм занятости. Аанный проџесс носит наименование «дигитализация труда» (digitalisation), что в переводе с английского означает «цифровизация», "оцифровка», ици перемещение информационного сегмента в цифровую плоскость. В настояшее время понятие «Аигитализаџия» часто встречается в научной митературе и характеризует общественные преобразования в экономической, правовой, соџиально-политической и Аругих сферах жизни человека, развивающихся под влиянием информаџионных технологий.

Их детальному изучению, связанному с трансформацией трудовых отношений, в рамках проџесса развития информационных технологий, посвящены работы О.А. Гришновой [1]. Среди зарубежных исследователей данной проблемой занимаются Р. Шимер [2], Б. Ейхенгрин, Т. Хэттон [3], Т. Ажаноски, А. Аюк, С. Оливер и ряд Аругих ученых [4-9]. 
Вместе с тем вопросы, связанные с обоснованием возможности использования цифровых технологий в сфере трудовых отношений, а также особенности функционирования цифровой занятости остаются недостаточно исследованными.

В Аанном исследовании ставились конкретные цели: изучение изменения политики трудовых отношений в связи с расширением цифровых технологий и преобразованием всех сфер общественной жизни; определении особенностей глобального рынка труда, состояния безработиџы в условиях дигитализации экономики, дается характеристика цифровой занятости как фактора решения проблемы безработицы.

Трудовые отношения в глобальном масштабе видоизменяются в связи с появлением цифровых технологий. Классическое понятие работника с накичием прав и обязанностей, трудового договора, рабочего места исчезает, формируется цифровая инфраструктура, труА работников перемешается в виртуальное пространство, что изменяет эмементы занятости и рынка труда.

Создание нового технологического социума способствует полномасштабной цифровизации и роботизации производства, уменьшает спрос на рабочую силу. Например, появление машинного производства в инАустриальный период породимо безработицу среди взрослых работников мужского пола. Их стали заменять женщины и дети [10]. Подобная ситуаџия может привести к невостребованности мимиионов работников в

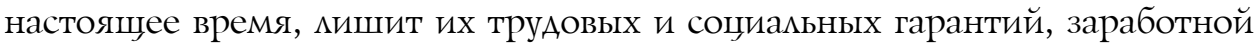
платы. Риск развития цифрового соџиума ведет к «гибкости трудовых отношений» с потерей традиционных гарантий трудовых соглашений. По мнению ученых, у работников может исчезнуть или снизиться соџиальный статус, а в обществе резко возрастет соџиальное неравенство. Следствием прекариатизации трудовых отношений является социальная деградация. А^я политического мироустройства это может обернуться существенным уменьшением социальных гарантий [2] .

Проблемное поле в формирующемся цифровом общественно-политическом и экономическом устройстве соџиума содержит ряА вопросов, требующих детального рассмотрения, среди которых можно выделить кАючевые в рамках данного исследования: каковы особенности содержания трудовых отношений в техногенном соџиуме; как Аигитализаџия может вАиять на занятость?

Учитывая имеющиеся разработки в сфере формирования цифровизации, можно выявить определенные закономерности, присушие глобальному феномену внедрения информационных технологий, дигитализации трудовых отношений и изменению структуры рынка занятости.

Во-первых, поскольку все сферы деятельности человека переходят на компьютерные технологии, формируется и постоянно расширяется цифровизация в трудовых отношениях, что способствует перемещению самой Аеятельности в интернет-пространство. При этом возникают нетипичные 
трудовые отношения в сфере осуществления цифровых работ: используется график гибкого рабочего времени, отсутствует закрепленное рабочее место работника и т.п. Итогом такой работы являются выполненные обязательства за определенное время.

Основными функциями развития цифровых отношений могут быть коммуникационная, интегральная и трансформационная. Если с коммуникационной составцяющей все понятно, то трансформационная вцияет на способы производства, интегральная аккумулирует потенџиал мирового развития [11]. Видоизменение среАств и способов производства формирует рынок труда и его цифровой сегмент.

Во-вторых, при расширении сетевых интернет-коммуникаций растет количество предложкений рабочей силы, поскольку возникает возможность удаленной работы и трудоустройства работников разных стран. Возникает конкуренция в новых трудовых отношениях. Работники IT-отрасли участвуют в создании цифровых технологий, поэтому трудовые отношения этой сферы наиболее интегрированы в цифровое сетевое мировое пространство. По сведениям информационного ресурса «Торsdev», наибольшее количество выполненных работ в Восточной Европе приходится на работников из Украины и России: 30 и 25\% соответственно. Показатели Румынии и Польши, Сербии и Болгарии составляют 5\%. В структуре оплаты труда за час рабочего времени фрилансеры из Польши занимают первое место (27 дом..); Болгарии - 25 дом.; Украины - 21 дом.. [12] .

В-третьих, в связи с выполнением трудовых обязанностей в сетевом пространстве появилось новое понятие «виртуальная миграция». Это касается тех случаев, когда работники, фактически не меняя места проживания, трудоустроены в IT-компании Аругой страны и дистанционно выполняют свои трудовые обязанности [12]. Снижению затрат при помучении прибыли работодателями развитых стран может способствовать наем работников из экономически неразвитых стран. При такой ситуации происходит изменение укоренившихся правовых элементов в трудовых отношениях: понятий рабочего места, рабочего времени, режима труда и отдыха, распорядка дня, имеющих ключевое значение в системе норм о труде.

В-четвертых, новый цифровой уклад вносит серьезные изменения в сложившиеся десятияетиями классические правоотношения межАу работодателем и работником, которые закреплены в трудовом законодательстве. Существенно изменяется подход к содержанию функциональных обязанностей работников: режким труда, отдыха, графика рабочего времени, его продолжительность, оплата произведенных работ. Особой проблемой становится регламентация прав сторон при возникновении спорных ситуаций. С учетом того, что трудовое соглашение закрепляется не при мичном контакте, а в сетевом пространстве с использованием цифровых подписей, то какова его законность? Специфической особенностью такого трудового 
правоотношения может быть отсутствие государственного регулирования как гаранта соблюдения прав сторон.

В связи с этим можно констатировать следующее:

a) трудовые правоотношения с использованием цифровых технологий не регламентированы действующим трудовым законодательством, поэтому их часто называют нестандартными или нетипичными. При их регулировании используют схожие нормы законодательства;

б) часто работодатели и работники явмяются гражданами разных госуАарств, в которых существуют свои внутренние нормы и порядок регулирования трудовых отношений;

в) Аигитализация трудовых отношений способна влиять на занятость и безработицу, уклонение от упцаты налогов работодатемями, отсутствие соџиального пакета у работников.

В-пятых, на содержание трудовых отношений и уровень безработиџы влияют экономические спады в мировой экономике. Важнейший из них мировой экономический кризис 2008-2009 гг., послеАствия которого еще сегодня не преодолены многими странами мира. В частности, в Греции уровень безработиџы увеличился с 8,3\% в 2008 г. Ао 24,2\% в 2013 г.; в Испании - с 8,4 до 25,2\%; на Кипре - с 3,0 до 15,8\%; в Ирландии с 4,6 до 13,1\%; в Португалии - с 8,0 до 16,5\% [13]. Кроме того, безработице как соџиально-экономическому явлению присуща опредеменная инерция, что создает дополнительные трудности с ее уменьшением. В настоящее время, когда пандемия COVID-19 охватила все страны мира, возможные последствия в виде экономического кризиса приобретут более масштабный характер по сравнению с 2008 г. Уровень безработиџы, спад производства и удар по трУАовым отношениям будет гораздо сильнее.

Аигитализация трудовых отношений влияет на уровень занятости. В связи с увеличением компьютерной роботизации работники становятся ненужными. Их функщии в сфере IT-технологий на рынке труда выполняют әлектронные технические устройства. Расширение виртуальной сети банковских, кассовых терминалов, интернет-платформ бронирования отелей, приобретения биметов, заказа и покупки предметов быта, эмектронных переводчиков и поисковых систем полностью или частично замешают работников.

Согласно исследованиям К. Фрей и М. Осборн, в ближайшее время окомо 40-50\% рабочих мест будут трансформированы или исчезнут с рынка труда [13]. Вместе с тем появятся новые цифровые рабочие места в технологических сферах деятельности, которые будут нуждаться в специальных профессиональных навыках. Такой вид безработиџы затронет развитые страны, где в сферу услуг активно внедряются цифровые технологии.

B-шестых, изменяется структура занятости на рынке труда. В частности, с окончанием индустриальной эпохи, в развитии экономики происходит постоянное расширение сферы услуг. По данным отчета Международной организации труда, в мире количество работников в сфере услуг выросло 
с 39,1\% в 2000 г. до 45,1\% в 2013 г. [14]. Это способствует увеличению нестандартных форм занятости, поскольку именно индустриальному сектору присуще использование стандартной занятости и, наоборот, сфера Аеятельности сектора услуг направлена на более гибкую занятость.

Гибкая занятость увеличивает требования к квацификационному уровню наемных работников. На рынке труда востребованы высококвалифицированные работники. К тому же на рынке труда присутствует большее количество работников с низкой и среАней квалификацией, что составляет около 45 и $37 \%$ соответственно. В трудовом проџессе применения цифровых технологий персонал высококвалифицированного уровня пользуется их помощью [14] .

Цифровизация трудовых отношений предполагает использование новых форм труда (фактическое отсутствие рабочего места, гибкий график труда и рабочего времени, удаленное осуществление трудовой функции, невозможкность заключения долгосрочных трудовых соглашений), в силу чего соџиальная защищенность работников отсутствует.

Цифровая занятость обладает мобильностью, что позволяет открыть ряд преимушеств и возможностей для работодателя и работника. Новые ІТ-технологии глобализируют трудовые отношения в рамках мирового рынка труда. Фактически мюбой работник при наличии профессиональной компетенции и доступа к сетевому пространству потенџиально явмяется участником трудовых отношений цифрового рынка труда. Он может виртуально трудоустроиться без изменения места своего проживания и получать заработную плату.

По результатам работы Всемирного экономического форума в Аавосе «Будущее трудоустройства», отмечены ключевые профессиональные навыки, необходимые для трудоустройства после 2020 г.: умение управмять персоналом, комплексное нестандартное решение вопросов, умение нешаблонно мыслить, креативность, партнерство, интемлект с эмоџиональным содержанием, цогика в принятии решений, гибкость в работе с клиентами [15]. Перечисленные навыки отражают способность к партнерству и управлению комлективом, интемлектуальные способности работника.

Таким образом, цифровизация трудовых отношений предполагает удаменную занятость, поэтому отсутствие территориальных ограничений может способствовать появлению рабочих мест без трудовой миграции, что обеспечит равновесие на региональных рынках и глобальном рынке труда.

Тенденции к сокращению офисных рабочих мест представляют социально-политическую проблему занятости в развитых странах. В такой ситуации основной задачей государственных и региональных институтов явмяется быстрое реагирование на проџесс переквалификации высвобожАаемой рабочей силы. Это поможет активно развить цифровой образовательный сегмент, необходимый дмя подготовки и переподготовки работников. В связи с этим цифровой образовательный сектор экономики 
можно рассматривать в разных аспектах. Прежде всего он будет создавать работников с новыми навыками, а затем сам станет площадкой, на которой будут возникать и аккумулироваться новые цифровые рабочие места.

Базовую цифровую занятость можно использовать как инструмент преодоления бедности и решения проблем безработиџы в наименее развитых странах. Оборудование рабочего места Аля базовой цифровой занятости явмяется низко затратным, поскольку Аця этого достаточно обеспечить компьютер с соответствующим программным обеспечением, Интернет, телефон. Аополнительным фактором является использование одного из европейских языков как офиџиальных (английского, французского, португальского). Примером создания условий такой цифровой занятости явмяется Инаия.

Цифровая базовая и смарт-занятость могут быть дополнительным фактором снижения категории NEET. Именно цифровая занятость, определенным образом воспроизводящая цифровые игровые действия, виртуальное взаимодействие в социальных платформах, может стать востребованной среди момодежки, которая относится к «цифровым аборигенам», с детства использующим IT-технологии дмя взаимодействия, развлечений, самореализаџии.

Цифровая смарт-занятость, бкагодаря своей инноваџионности, явцяется конкурентным преимуществом и фактором обеспечения экономического роста и благосостояния как отдельной страны, так и глобальной экономики в целом. Приоритетным направлением дмя исследований может быть использование цифровизации трудовых отношений в качестве способа преодоления безработиџы в Российской Федерации, а также ее правовая регламентация. Аискуссионными остаются некоторые экономические, правовые, социальные, политические аспекты дигитализации трудовых отношений.

Цифровое технологическое переустройство политической, экономической сфер имеет тенденцию к обострению интересов работников и работодателей, что повлечет давление на внутригосударственные отношения в области соџиальной политики. Человек в условиях цифровой экономики становится механизмом расчета и перераспределения общественного проАукта на основе количественных данных. Его роль в «цифровом» социальном государстве может быть нивелирована к минимальным соџиальным запросам, ограниченным домей в общей массе соџиальных услуг. Именно поэтому цифровое общество способно стать постгуманистическим.

Цифровизация трудовых отношений в условиях российского общества не Аолжна негативно влиять на работников, поскольку призвана всесторонне улучшать развитие политического и обшественно-экономического укцадов. Безусловно, оцифровка и переформатирование трудовых отношений обладают мощным техническим потенциалом, который окажет вцияние на кажАого человека.

ГАубокое изучение вопросов цифровизации трудовых отношений позволит проанализировать соџиально-политические риски в России после 
принятия стратегии цифрового развития и выявить специфические посмедствия функционирования техногенного социума в российских реалиях. В настоящее время ключевой проблемой явмяется совместимость мирового и внутригосударственного социального и технологического устоев трудовых отношений дмя сохранения социокультурных и национальных особенностей России в условиях глобальной цифровизаџии соџиума.

\section{Библиографический список}

1. Гришнова О.А. Информационные технологии в системе новых способов роста продуктивности труда: тенденции и парадоксы // Актуальные проблемы экономики. 2014. № 2 (152). C. 462-469.

2. Shimer R. Reassessing the Ins and Outs of Unemployment // Review of Economic Dynamics. 2012. Vol. 15, No. 2. P. 127-148. URL: http://www.tau.ac.il/ yashiv/shim er_red.pdf

3. Eichengreen B.J., Hatton T.J. Interwar Unemployment in International Perspective // Springer Science \& Business Media. 2012. Vol. 43. URL: http://irle.berkeley.edu/workingpapers/12-88.pdf

4. Janoski T., Luke D., Oliver C. The Causes of Structural Unemployment: Four Factors that Keep People from the Jobs They Deserve // John Wiley \& Sons. 2014. URL: https://works.be press.com/thomasjanoski/15

5. O'Reilly J. Five Characteristics of Youth Unemployment in Europe // Sage Open. 2015. No. 5 (1). URL: http://sgo.sagepub.com /content/5/1/2158244015574962.full

6. Katz L. Long-Term Unemployment in the Great Recession // Members Only Library. 2014. URL: http://www.scholar.harvard. edu/files/lkatz/files/long_term_unemployment_in_ the_great_recession.pdf

7. Brynjolfsson E., McAfee A. Race Against the Machine: How the Digital Revolution is Accelerating Innovation, Driving Productivity, and Irreversibly Transforming Employment and the Economy 2012. URL: http://digital.mit.edu/re search/briefs/brynjolfsson_McAfee_Race_ Against_the_Machine.pdf

8. Rogan M., Diga K., Valodia I. Labour Market Analysis and Business Process Services in South Africa: Poverty Reduction through Information and Digital Employment Initiative // University of KwaZulu-Natal. 2013. URL: http://sds.ukzn.ac.za/Files/Documents/Research-Publications/ITEM2 researchpaper_SA_FINAL_Aug2013.pdf

9. Ramalingam B. Can Digital Jobs Solve Africa's Unemployment Crisis. 2016. URL: http:// opendocs. ids.ac.uk/opendocs/bitstream/handle/123456789/8835/RRB13.pdf?seque nce=1

10. «Капитал» К. Маркса и проблемы современного капитализма / под ред. Н.А. Цаголова, В.И. Кирова. М., 1968.

11. Дейнека Т.А. Противоречия современной технико-экономической парадигмы в условиях информационной глобализации // Экономика развития. 2015. № 4 (76). С. 13-21.

12. Рынок фриланс-аутсорса Восточной Европы в 2015 г. URL: http://topsdev.org/blog/ obzor-rinka-freelance-2015.htm

13. Unemployment on the Rise over Next Five Years as Inequality Persists: World Employment and Social Outlook - Trends 2015. URL: http:/www.ilo.org/global/about-the-ilo/newsroom/news/WCMS_336884/langen/index.htm

14. World Employment and Social Outlook - Trends 2015. URL: http://www.ilo.org/wcmsp5/groups/public/ dgreports/dcomm/publ/documents/publication/wcms_337069.pdf

15. The 10 Skills you Need to Thrive in the Fourth Industrial Revolution/ The World Economic Forum. URL: http://www.we forum.org/agenda/2016/01/the-10-skills-you-need-to-thrive-in-the-fourthindustrial-revolution?utm_content $=$ buffer $7 \mathrm{f0} 5 \mathrm{c} \& u t m \_$mdium $=$social\&utm_source=facebook 